\title{
Dinamika Ideologi Karman dalam Novel Kubah Karya Ahmad Tohari Berdasarkan Perspektif Sosiologi Sastra Marxisme
}

\author{
Abdul Basid, Zahrah Nida' Rosyida AsSulthoni \\ Fakultas Humaniora, Universitas Islam Negeri Maulana Malik Ibrahim Malang \\ abdulbasid@bsa.uin-malang.ac.id
}

\begin{abstract}
How to cite (in APA Style): Basid, A., \& As Sulthoni, Z.N.R. (2018). Dinamika ideologi Karman dalam novel Kubah karya Ahmad Tohari berdasarkan perspektif sosiologi sastra marxisme.Jurnal Pendidikan Bahasa dan Sastra, 18(1),58-68, doi: 10.17509/bs_jpbsp.v18i1.12146.
\end{abstract}

Article History: Received (July 9, 2017); Revised (January 16, 2018); Accepted (February 25, 2018).

Journal homepage: http://ejournal.upi.edu./index.php/BS_JPBSP

\begin{abstract}
This study aims to analyze the dynamics of ideology that occurred on the main character named Karman in a novel 'Kubah' by Ahmad Tohari. The analysis uses Marx's literary sociology theory which focuses on the grouping of society classes based on their infrastructure and superstructure in literary works. The exposure analysis includes; (1) discussion of ideological conceptualization, (2) discussion of Marx's sociology of novel 'Kubah' paradigm of social class structure relation in society which include: (a) the analysis of the social class structure of literature, i.e. identification of social background into the context of the occurrence, identification of social classes, the analysis of social activities that occur among social classes represented in interrelated relations, and (b) the literary social class structure relation with the social class structure of society. Based on the analysis, we would discover the form, cause, and impact of Karman's ideological dynamics on Pegaten society.
\end{abstract}

Kata kunci: ideology, novel, sosiology, literary marxisme

\section{The Dynamics of Karman Ideology in Novel Kubah of Ahmad Tohari Based on Perspective of Marx's Literary Sociology}

\begin{abstract}
Abstrak: Penelitian ini bertujuan untuk menganalisis dinamika ideologi yang terjadi pada tokoh utama bernama Karman dalam novel 'Kubah' oleh Ahmad Tohari. Analisis ini menggunakan teori sosiologi sastra Marx yang berfokus pada pengelompokan kelas masyarakat berdasarkan infrastruktur dan suprastruktur dalam karya sastra. Analisis paparan meliputi; (1) diskusi tentang konseptualisasi ideologis, (2) pembahasan sosiologi Marx tentang paradigma 'Kubah' novel relasi struktur kelas sosial dalam masyarakat yang meliputi: (a) analisis struktur kelas sosial sastra, yaitu identifikasi latar belakang sosial ke dalam konteks terjadinya, identifikasi kelas-kelas sosial, analisis kegiatan-kegiatan sosial yang terjadi di antara kelas-kelas sosial yang direpresentasikan dalam hubungan-hubungan yang saling terkait, dan (b) hubungan struktur kelas sosial sastra dengan struktur kelas sosial masyarakat. Berdasarkan analisis, kami menemukan bentuk, penyebab, dan dampak dari dinamika ideologis Karman pada masyarakat Pegaten.

Keywords:ideologi, novel, sosiologi, sastra marxisme
\end{abstract}




\section{PENDAHULUAN}

Ideologi dalam sastra merupakan suatu perspektif yang berhubungan dengan posisi kelas, pandangan, dan sisi kehidupan yang faktanya seringkali diputar balikkan. Namun secara garis besar, ideologi berhubungan dengan proses pembenaran dominasi yakni adanya pembenaran hubungan kekuasaan yang tidak seimbang. Begitupun dengan apa yang diungkapkan Marx dalam kritik ideologinya, bahwa ideologi adalah ajaran yang menjelaskan suatu struktur kekuasaan yang dirancang sedemikian rupa, sehingga orang menganggapnya sah, padahal jelas tidak sah. Ideologi melayani kepentingan kelas berkuasa karena memberikan legitimasi kepada suatu keadaan yang sebenarnya tidak memiliki legitimasi.

Ideologi merupakan hal pokok yang dimiliki setiap orang. Baik dalam kehidupan nyata maupun ideologi yang dibebankan kepada seorang tokoh dalam karya sastra. Setiap tokoh dalam sebuah sastra pasti akan mengalami peristiwa-peristiwa sosial dalam dunia imajinatifnya. Sesuai dengan yang disampaikan Aminuddin bahwa pelaku adalah pengemban peristiwa dalam cerita fiksi sehingga peristiwa itu mampu menjalin suatu cerita disebut dengan tokoh. Ideologi disini berperan sebagai bentuk pemikiran tokoh dalam menghadapi masalah yang terdapat dalam karya sastra (Aminuddin, 2002,p. 79).

Sebagaimana yang terkisah dalam novel berjudul Kubah yang mengambil latar belakang sosial peristiwa G30S PKI. Kubah merupakan sebuah novel yang menceritakan tentang Karman, seorang pria miskin yang terjebak dalam pergolakan politik Indonesia pada tahun 1950-an. Ia adalah pemuda yang baik, tulus, cerdas, dan lugu. Namun keluguan dan ketulusan hatinya membuat ia mudah dimanfaatkan oleh pihak yang berkepentingan.

Dinamika ideologi tokoh Karman disebabkan oleh kondisi lingkungan dan beban hidup yang dialaminya, yaitu pengaruh latar belakang peristiwa novel yang merupakan salah satu kejadian dahsyat yang pernah terjadi di negeri ini. Perubahan sikap dan watak Karman akibat hasutan tokoh lain, yang dalam hal ini, menempati kelas atas pada ranah sosial. Karman sebagai representasi dari kelas bawah tatanan masyarakat hanya dapat menerima perlakuan tokoh kelas atas sebagai kesadaran semu. Kelihaian para tokoh kelas atas menjadikan stratifikasi sosial antarkelas tidak nampak jelas, sehingga mereka dengan mudah mengontrol Karman. Apalagi ideologi terselubung PKI yang dijunjung, diintegrasikan sedemikian rupa dengan nilai keguyuban dan humanisme masyarakat.

Pertemuan Karman dengan Margo dan Triman yang merupakan kader PKI juga membawa dampak yang nyata bagi pandangannya terhadap status agama sebagai lembaga atau sistem sosial masyarakat. Pandangan Marxisme yang ditanamkan Margo dan Triman pada Karman membuatnya antipati terhadap agama. Hal ini didorong rasa sakit hatinya kepada Haji Bakir, seorang tokoh agama di desa Pegaten. Awal mulanya, karena ia merasa Haji Bakir tidak menginginkannya menjadi menantu atau suami dari anak perempuan satu-satunya, Rifah. Karena kejadian ini ia menjadi antipati terhadap agama.

Menurut Marx, agama adalah candu rakyat. Ini adalah kritik Marx yang paling terkenal. Candu itu memberikan kepuasan, tetapi kepuasan itu semu karena tidak merubah situasi buruk si pecandu. Agama menjanjikan ganjaran di akhirat bagi orang yang dengan tabah menerima "nasib" atau "salibnya". Maka, rakyat kecil bukanlah memperjuangkan perbaikan nasib mereka, tetapi malah bersedia menerima penghisapan dan penindasan yang dideritanya (Suseno, 1999,p. 123).

Perlu diperhatikan bahwa ideologi dalam arti yang sebenarnya bukan sarana yang dipakai oleh kelas-kelas atas untuk menipu. Ideologi betul-betul dipercayai oleh seluruh masyarakat dengan polos. Karena itu dia begitu kuat. Si kapitalis secara subjektif jujur apabila ia yakin bahwa siapa saja yang dengan setia memenuhi kewajibannya masing-masing adalah memenuhi kehendak Tuhan. Tetapi mengapa agama, moralitas, nilai-nilai budaya, dan sebagainya selalu dan dengan sendirinya menguntungkan kelas-kelas atas? Karena, sebagaimana ditulis oleh Marx dan dikutip 
oleh Suseno, "pikiran-pikiran kelas berkuasa di setiap zaman merupakan pikiran-pikiran yang berkuasa, artinya, kelas yang merupakan kekuatan material masyarakat yang berkuasa sekaligus merupakan kekuatan spiritual masyarakat?". Mengapa demikian? Karena hanya kelas-kelas yang "menguasai saranasarana produksi material sekaligus menguasai sarana-sarana produksi spiritual" (Suseno, 1999,p. 124).

Dari penjabaran tentang teori Karl Marx di atas, maka dapat ditarik kesimpulan bahwa menurut Karl Marx, motor perubahan dan perkembangan masyarakat adalah pertentangan antar kelas-kelas sosial. Kepentingan tidak terletak pada minat orangorang tertentu, namun dalam proses produksi secara objektif sudah ditetapkan oleh kelas masing-masing.

Berdasarkan apa yang sudah peneliti paparkan di atas, peneliti menggunakan teori sastra Marxis untuk mengkaji fenomena dinamika ideologi Karman. Fenomena dinamika perwatakan yang terjadi merupakan realita yang dialami oleh tokoh utama, yaitu Karman, sebagai respon atau reaksi terhadap relasi antartokoh dalam konteks latar sosial dan alur sebagai peristiwa. Teori sosiologi sastra Marxis tepat digunakan karena menawarkan paradigma kelas sosial dimana fokus analisis terletak pada relasi antartokoh dalam konteks latar sosial dan alur sebagai peristiwa, sehingga aspek sosiologi yang berfokus pada relasi tokoh sebagai individu kolektif yang bertindak sosial dapat dapat diidentifikasi.

\section{METODE}

Penelitian ini bertujuan untuk menemukan dan memaparkan ideologi dari tokoh utama bernama Karman dalam novel berjudul Kubah karya Ahmad Tohari. Berdasarkan tujuan tersebut maka penelitian ini disebut penelitian deskriprif analisis. Menurut Ratna deskriptif analisis dilakukan dengan cara pendeskripsian fakta-fakta yang kemudian disusul dengan analisis (Ratna, 2009,p. 53). Penelitian ini juga disebut penelitian kualitatif. Fraenkel dan Wallen dikutip oleh Suharsaputra menyatakan bahwa penelitian kualitatif berarti mengkaji kualitas hubungan atau material dengan penekanan kuat pada deskripsi menyeluruh dalam menggambarkan rincian segala sesuatu yang terjadi pada situasi tertentu (Suharsaputra, 2012,p. 181).

Dalam studi penelitian teori sastra Marx ini peneliti menggunakan paradigma yang menganalisis relasi struktur kelas sosial sastra dengan masyarakat. Analisis tersebut mencakup struktur kelas sosial sastra, relasi struktur kelas sosial sastra dengan struktur kelas sosial masyarakat, dan identifikasi kelas sosial pengarang.

Sumber data primer yang digunakan adalah novel Kubah karya Ahmad Tohari. Sedangkan sumber data penunjang berupa buku-buku dan artikel mengenai ideologi, pemikiran Karl Marx, jurnal yang membahas ideologi khususnya Marxisme, teori sastra, dan seputar penelitian sastra. Adapun teknik pengumpulan data, peneliti menggunakan teknik baca simbolik dan semantik, serta teknik catat quotasi dan parafrase yang kemudian dikelompokkan sesuai dengan kategori data yang diperlukan (Kaelan, 2012,p. 164-167).

Untuk memverifikasi data yang sudah didapatkan, peneliti melakukan validasi data dengan menggunakan uji kreadibilitas. Langkah ini terdiri atas tiga tahap, yaitu: meningkatkan ketekunan, triangulasi, dan diskusi dengan teman ahli atau sejawat (Sugiyono, 2015,p. 267) Sedangkan teknik analisis data yang digunakan dalam penelitian ini adalah model analisis Miles dan Hubermann yang terdiri dari empat langkah, yaitu:data collection (pengumpulan data), data reduction (reduksi data), data display (penyajian data), conclusion drawing (penarikan atau verifikasi kesimpulan) (Hubermann, 1994,p. 30).

\section{HASIL DAN PEMBAHASAN}

Hasil penelitian yang dipaparkan melingkupi: a) konseptualisasi ideologi; b) analisis sosiologi Marx terhadap novel Kubah karya Ahmad Tohari paradigma relasi struktur kelas sosial dalam masyarakat yang meliputi: 1) analisis struktur kelas sosial sastra, yaitu identifikasi latar sosial yang menjadi konteks 
terjadinya peristiwa, identifikasi kelas-kelas sosial, analisis aktivitas-aktivitas sosial yang terjadi antarkelas sosial yang direpresentasikan dalam relasi antartokoh, dan 2) relasi struktur kelas sosial sastra dengan struktur kelas sosial masyarakat.

\section{A. Konseptualisasi Ideologi}

$\begin{array}{lr}\text { Marx menggunakan istilah } \\ \text { ideologi untuk merujuk kepada } & \text { sistem- } \\ \text { sistem aturan ide-ide yang }\end{array}$ menyembunyikan kontradiksi-kontradiksi yang berada pada pusat sistem. Pada banyak kasus, ideologi dapat dipahami sebagai (1) suatu sistem-agama, filsafat, sastra, dan hukum-yang menjadikan kontradiksi antarkelas tampak koheren, (2) suatu pengalaman-pengalaman yang mengungkapkan kontradiksi-kontradiksi sebagai problem personal atau keanehankeanehan individual, dan (3) sistem yang menghadirkan kontradiksi kelas sebagai suatu kontradiksi pada hakikat manusia yang tidak bisa dipenuhi oleh perubahan (Ritzer \& Goodman, 2011,p.71). Adapun konseptualisasi ideologi dalam novel Kubah karya Ahmad Tohari dapat dijabarkan sebagai berikut:

1. Ideologi Tertutup

Tanda pengenalan mengenai ideologi tertutup adalah bahwa isinya bukan hanya berupa nilai-nilai dan cita-cita tertentu, melainkan intinya terdiri dari tuntunan-tuntunan kongret dan operasional yang keras, yang diajukan dengan mutlak.Hal itu juga berarti orang harus taat kepada elite yang mengembannya, taat terhadap tuntunan ideologi dan tuntutan ketaatan itu mutlak dari nuraninya, tanggung jawabnya atas hak-hak asasinya. Kekuasaan selalu condong ke arah total, jadi besifat totaliter dan akan menyangkut segala segi kehidupan.

Tentang Haji Bakir, kedua orang partai itu berpropaganda kepada Karman:
"Kebaikan yang pernab ia berikan kepadamu adalah contoh kemunafikan yang nyata. Takekan pernah ia menolongmu, menyantunimu ketika kau masib kanak-kanak, apabila tidak melihat keutnungan yang dapat diperoleb darimu. Tenagamu, misalnya! Jadi tidak mengherankan apabila Haji Bakir menolak lamaranmu. Seorang tuan tanah selalu jahat, tidak berperikemanusiaan. Pasti ia menganggap kau tidak pantas menjadi menantunya karena kau keturunan rakyat jelata. Bukan karena kau datang terlambat. Bukan! Tetapi karena kau miskin dan Abdul Rabman anak orang terkaya juga.

Mereka orang-orang kaya adalab kaum penindas yang secara bistoris selalu mempertahankan kelestarian kelasnya. Mereka tidak ingin seorang seperti engkau masuk ke dalam kalangan mereka. Sadarlab kau sekarang, betapa jahat kaum tuan tanah itu." (p. 92-93)

Sesuai dengan penjelasan kutipan-kutipan di atas, maka pada tahap ini Karman memiliki ideologi komunis yang dapat digolongkan dalam ideologi tertutup. Ideologi ini sebagai bentuk reaksi atas perkembangan sistem masyarakat kapitalis yang dipengaruhi paham liberal. Menurut ideologi komunis, sistem masyarakat kapitalis menyebabkan penderitaan rakyat karena menindas dan mengesampingkan peran rakyat kecil. Margo membuat Karman memiliki pembenaran hubungan kekuasaan yang tidak simetris, yaitu misi memutarbalikkan fakta mengenai kebaikan-kebaikan Haji Bakir pada hidup Karman semasa kecil. Menjadikan hal itu adalah hal yang salah karena telah memanfaatkan tenaganya sebagai anak kecil. Kenaifan Karman menilai kejadian di masa lalu itu sebagai ketidakadilan yang diterimanya sebagai rakyat miskin. 
Karman tersentak.ia tabu apa yang dimaksud dengan mengisap candu seperti yang diucapkan Margo. Ia masih ingat bahwa bagi kaum Marxis, agama adalah candu untuk menindabobokkan kaum tertindas agar tertidur dari rasa ingin menuntut hak-hak mereka. Merah padam mukanya. Karman bangkit menggedor meja. Bangkit untuk membela seorang perempuan yang baginya adalab kesejukan bidup. Bangkit untuk. membela seorang perempuan yang mempunyai lekuk ujung bibir paling bagus di dunia. Karman bukan menggedor meja karena ingin berpihak. pada kaum reaksioner. Tetapi demi Marni, hanya Marni. (p. 130)

Kejadian ini menunjukkan salah satu bentuk lembaga sosial masyarakat Pegaten yakni agama. Hal ini dipengaruhi oleh aktifitas-aktifitas produksi (infrastruktur) yang membawa perubahan pada superstruktur yang berkembang di masyarakat. Marni memiliki struktur kepercayaan yang berbanding terbalik dengan apa yang diyakini Karman, sehingga mempengaruhi ide dan konsep intelektualitasnya.

2. Ideologi Terbuka

Adapun ciri ideologi terbuka adalah bahwa nilai-nilai dan citacitanya tidak dipaksakan dari luar, melainkan digali dan diambil dari harta kekayaan rohani, moral dan budaya masyarakat itu sendiri, jadi yang berlaku diideologi tetutup tidak berlaku diideologi terbuka. Ideologi terbuka digali dalam masyarakat, ia tidak diciptakan atau didikte oleh penguasa.

Karman mendengar puji-pujian itu. rasanya dia yakin babwa dirinya tidak berbak menerima semua pujian itu. tetapi wajah orang-orang Pegaten yang berhias senyum, sikap mereka yang makin ramah. Membuat Karman merasa sangat bahagia.
Karman sudab melihat jalan kembali menuju kebersamaan dan kesetaraan dalam pergaulan yang hingga hari-hari kemarin terasa mengucilkan dirinya. Oh, kubah yang sederhana itu! dalam kebisuannya, mabkota masjid itu terasa terus mengumandangkan janji akan memberikan harga asasi kepada setiap manusia yang sadar akan kemanusiannya. Dan Karman merasa tidak terkecuali. (p. 189)

Kutipan di atas merupakan peristiwa terakhir dalam novel di mana Karman kembali lagi pada ideologinya sebagai bagian dari masyarakat Pegaten. Konsensus tatanan masyarakat tidak sempurna yang awalnya ia tolak, pada tahap ini, menjadi bukan masalah. Karena kontradiksi antar kelas yang terjadi dalam suatu masyarakat memang tidak dapat dinafikan.

Pada tahap ini yang kemudian menjadi ideologi Karman adalah ideologi terbuka Pancasila. Pancasila sebagai ideologi bangsa Indonesia berfungsi sebagai cita-cita negara yang menjadi basis bagi suatu teori atau sistem kenegaraan untuk seluruh rakyat dan bangsa Indonesia. Selain itu juga menjadi tujuan hidup berbangsa dan bernegara Indonesia.

Dengan demikian, ideologi menurut Marx merupakan kesadaran, keyakinan, ide, dan gagasan yang dipercaya masyarakat yang menjadikan kontradiksi kelas itu tidak tampak atau sebaliknya. Oleh karena itu, menurut pendapat Marx, yang dikutip oleh Jones, mengidentifikasi dua bentuk ideologi sebagai hasil kesadaran manusia, yaitu (Kurniawan, 2012,p.43):

a. Ideologi kesadaran kelas.

"Paman, bagaimana aku akan mengatakan adil bila satu setengab bektar sawah hanya ditukar dengan satu ton padi? Pokoknya tidak adil. Sudah bagus bila aku tidak menuntut sawah itu kembali. Mengapa aku barus berbaik terhadap orang yang 
menyebabkan seisi rumabku sengsara?" (p.. 99)

Karman sebagai wakil dari bagian masyarakat subordinat memandang realitas, dalam hal ini, berupa transaksi jual-beli yang dilakukan ayahnya dan Haji Bakir sebagai sesuatu yang salah. Meski secara sistem benar, namun ide akibat propaganda dari Margo menimbulkan kesadaran pada dirinya tentang eksistensinya sebagai suatu kelas ekonomi yang dipinggirkan.

b. Ideologi kesadaran semu.

Apa yang mendorong Karman
memutuskan ikut berlibur ke
Semarang, ia sendiri tidak dapat
memastikan. Boleh jadi ia benar-
benar ingin melihat kota itu, atau
karena ia selama ini tidak mampu
menolak kehendak Triman. (p.
108)

Sikap Karman ini merupakan kesadaran yang tidak muncul bebas dari kondisi ekonomi, melainkan sikap patuh karena campur tangan Triman mengenai kepegawaian Karman. Hal ini berhubungan dengan syarat yang diajukan Triman sebagai bentuk balas budi, yaitu rasa terimakasih. Terdengar sepele, namun menjadi pegawai adalah hal berharga dalam hidup Karman. Sehingga terhadap Triman, hubungan antar kelas menjadi bias dan menjadi kesadaran semu.

Ideologi kesadaran kelas dan kesadaran semu inilah yang menjadikan kelas subordinat memahami kedudukannya sebagai kelas yang tereksploitasi, sehingga mereka pun memulai perjuangan politik yang dirancang untuk menggantikan tatanan sosial yang lama dengan yang baru, yang lebih sesuai dengan tatanan ekonomi yang baru (Saifuddin, 2009,p. 92).

\section{B. Analisis Sosiologi Sastra Marxis}

Marx meyakini bahwa situasi dan kondisi sosial manusia sangat dipengaruhi oleh aspek material-produksi. Oleh karena itu Marx mengidentifikasi struktur sosial masyarakat menjadi dua kelas: kelas atas dan kelas bawah yang faktor utamanya didasarkan pada penguasaan alat alat produksi pada zamannya. Setiap perkembangan zaman sebenarnya memiliki struktur sosialnya sendiri, tetapi bagi Marx, sekalipun struktur sosial itu berbeda, tetapi substansi pola determinasi antar kelasnya sama. Jadi, munculnya kelas-kelas sosial dalam masyarakat, menurut Marx, didasarkan pada penguasaan alat produksi, maka kelas atas adalah kelas yang memiliki sarana produksi, sedangkan kelas bawah adalah kelas yang tidak memiliki alat alat produksi. Relasi antar kelas ini yang kemudian menciptakan kelas dominan dengan subordinat, majikan dengan budak, tuan rumah dengan pelayan, dan borjuis dengan proletar. Relasi hubungan antar kelas ini didasarkan pada faktor determinasi ekonomi (Kurniawan, 2012,p. 42). Adapun analisis sosiologi sastra Marxis terhadap novel Kubah karya Ahmad Tohari paradigma relasi struktur kelas sosial dalam masyarakat dapat dijabarkan sebagai berikut:

1. Analisis struktur kelas sosial sastra

Dengan melihat sastra sebagai "dunia" yang dimediakan dengan kata, maka fokus analisis sosiologi sastra adalah pada relasi antartokoh dalam konteks latar sosial dan alur sebagai peristiwa. Dari relasi ketiga unsur ini (tokoh, latar, dan alur), maka aspek sosiologi, yang berfokus pada relasi tokoh sebagai individu kolektif yang bertindak sosial dapat diidentifikasi.

a. Identifikasi Latar Sosial

Latar sosial adalah ruang kehidupan sosial yang mengorganisasi segala bentuk aktivitas sosial dalam sastra. Aktivitas sosial ini bisa dilihat dengan mengidentifikasi hubungan 
atau relasi yang terjadi antartokoh. Latar sosial dalam sastra tentu saja tidak bersifat tunggal, tapi berlapislapis.

"Karman, Pak Triman. Betapa saya
ingin menyekolabkan dia sampai
tingkat menengah atas, tetapi tak
dapat. Anak saya sendiri sudah
waktunya membutubkan biaya.
Karman anak yang biak, pintar.
Sayang ia harus puas dengan ijazah
SMP. Sekarang Karman kusuruh
mencari pekerjaan. Apa boleh buat."
(p. 82$)$

Kutipan ini menggambarkan latar Karman sebagai masyarakat desa kelas bawah, yaitu kelompok yang tidak memiliki modal atau kekuasaan untuk menghasilkan pendapatan. Maka yang terjadi adalah ketergantungan terhadap pemilik modal, dalam hal ini Triman. Meski bukan 'pemilik modal' secara harfiah, namun Triman memiliki kekuasaan yang dapat mengangkat harkat kehidupan Karman. Sikap Triman dapat dikatakan sebagai bentuk nilai keguyuban dan kemanusiaan sebagai masyarakat desa. Meski yang terjadi sesungguhnya adalah jebakan halus bagi Karman.

Orang yang teliti dan cukup berbesar
jiwa, bisa memahami pada saat itu
sedang terjadi persaingan antara tiga
kekuatan. Masing-masing memiliki
laskar bersenjata, masing-masing
menaurh kepentingan atas wilayah
Pegaten dan sekitarmya... (p. 122-
123)

Pada kutipan di atas memperlihatkan keadaan Indonesia tahun lima puluhan dimana gerakan Komunis mulai mengakar. Pemuda-pemuda seperti Karman menjadi sasaran penanaman propaganda anti-pemerintah berkedok revolusi. Sebagai masyarakat desa yang lugu dan taat agama, pada awalnya, Karman mulai terpengaruh disebabkan mereka menawarkan jalan keluar dari kehidupannya yang sengsara.

Yang terjadi di Pegaten pada awal
tahun enam puluban, sama seperti
yang terjadi di mana-mana. Boleh jadi
orang tidak senang mengingat masa
itu kembali karena kepahitan hidup
yang terjadi waktu itu. (p. 132)

Selanjutnya adalah Indonesia di tahun enam puluhan, saat makar berdarah pecah di Jakarta. Tak ada pilihan bagi pemerintah orde baru untuk mempertahankan stabilitas negara selain dengan menumpas oknumoknum penyulut huru-hara. Adapun bukti yang mengacu bahwa konteks sosial dalam novel Kubah itu berlatarkan pemerintahan orde baru adalah: (1) terjadinya makar berdarah di Jakarta; (2) gerakan revolusi yang diusung Margo, Triman, dan kawan-kawan; (3) nilai-nilai komunis yang dipertentangkan dalam sepanjang kisah Karman.

b. Identifikasi Kelas-kelas Sosial

Kelas sosial ini menyangkut identifikasi kelas dalam konteks pemilikan alat-alat produksi, sehingga akan memunculkan dua kelas sosial. Penentuan kelas sosialnya didasarkan pada basis ekonomi.

1) Kelas Atas

Hari-hari selanjutnya,
Karman dan adiknya
mendapat perhatian yang
cukup dari keluarga Haji
Bakir. Selalu ada pekerjaan
kecil-kecilan yang bisa
dikerjakan Karman sementara
anak itu momong adiknya.
Dengan memberi pekerjaan
kecil, Bu Haji bermaksud
mendidik Karman sehingga ia


tidak terbiasa bergantung

kepada pemberian orang..... p.

59)

Latar sosial dalam peristiwa ini adalah pedesaan dimana Haji Bakir menjadi representasi orang kaya yang memiliki modal usaha atau tuan tanah. Meski dalam teori Marx tuan tanah digambarkan sebagai kelas yang mengintimidasi rakyat kecil, namun dalam novel Kubah ini Ahmad Tohari menggambarkan keluarga Haji Bakir sebagai bagian masyarakat yang baik. Hal ini terlihat dari sikap yang ditunjukkan pada Karman sebagai orang miskin.

"Yah, tentu saja berusaba menanam jasa kepada dia. Sudah saya laporkan, saat ini Karman sangat membutubkan pekerjaan. Apabila dia bisa menjadi pegawai atas bantuan kita, maka perkenalan dia dengan kita berlangsung sangat wajar dan mulus. Jadi pertanyaan saya saat ini adalah: apakah ada lowongan pekerjaan yang bisa kita berikan kepada Karman?” (p.79)

Dalam hal ini Triman memang bukan pemegang langsung modal usaha, alat-alat produksi yang ia miliki berasal dari imbalan atas tugas-tugasnya, namun ia berperan dalam penyediaan lapangan pekerjaan untuk Karman. Dalam hal ini Triman melakukan muslihat sebagai kelas atas sehingga menimbulkan hutang budi untuk selamanya. Maka dari itu Triman dapat mudah menanamkan propaganda Komunis karena telah berhasil mengikat Karman dengan rasa terimakasihnya.

2) Kelas Bawah

\begin{abstract}
Karman tabu Bu Mantri, ibunya, tak pandai menuai. Jadi bagaimanapun baiknya panen musim itu, Bu Mantri tidak akan mendapat bawon, yaitu upah menuai padi. Padi yang diterima dari Haji Bakir sebagai upah Karman sudab habis, karena sebagian dijual untuk keperluan lain. "Tak pantas pada waktu panen seperti ini ibuku tak punya beras. Sebaiknya aku ikut menuai padi agar ibuku sempat merasakan nasi yang empuk." (p. 63)
\end{abstract}

Dari kutipan di atas Karman menjadi representasi yang tepat sebagai kelas bawah dalam teori Marx. Karman yang harus menuai padi pada pemilik sawah demi mendapat beras menandakan penguasaan materi ekonomi yang rendah. Karman menjadi bagian masyarakat yang tidak memiliki modal sehingga untuk menunjang hidupnya harus bergantung pada pemilik modal atau tuan tanah yang disebut kaum borjuis.

c. Analisis Aktifitas-aktifitas Sosial dalam Relasi Antartokoh

Konflik kelas sosial ditelaah dari aspek ideologis sosial, yaitu keberadaan ideologi antarkelas yang menyebabkan terjadinya konflik sosial antarkelas. Dengan mengidentifikasi dan menganalisis ideologi kelas ini, maka bisa diungkap tentang kelas sosial yang dimenangkan dalam konflik sosial tersebut.

1) Karman dengan Margo dan Triman

Secara berkala Triman mengunjungi anak binaannya yang baru. Diberikannya petunjuk-petunjuk yang perlu diperbatikan oleh seorang calon pegawai. Ia bersikap seperti seorang ayah yang amat 


memperhatikan kepentingan
anaknya. Pengarub serta
wibawa ditanamkan di hati
anak muda itu dengan
perbitungan yang seksama.
Sementara, Karman tak bisa
berbuat lain kecuali selalu
bersikap hormat kepada para
penolongnya. (p.87)

Seperti yang sudah dijelaskan sebelumnya, Triman merupakan representasi kelas atas dan Karman sebagai kelas bawah. Hubungan antar kelas sosial ini menimbulkan kesadaran semu pada diri Karman, sehingga ia tidak dapat menolak apapun yang ditawarkan Triman.

2) Karman dengan masyarakat Pegaten

Di rumah orangtuanya, Karman sedang dirubung oleh para tamu, tetangga-tetangga yang sudah amat lama ditinggalkean. Ia merasa beran dan terharu, ternyata orang-orang Pegaten tetap pada watak mereka yang asli. Ramah, bersaudara, dan yang penting: gampang melupakan kesalahan orang lain. Padahal yang sanagt dikhawatirkan oleh Karman adalab sikap membenci dan dendam yang mungkin diterimanya begitu ia muncul kembali di Pegaten....(p. 173)

Kutipan di atas menggambarkan hubungan relasi antarkelas dalam konteks sosial masyarakat desa tidak menjadi persoalan. Hal ini dikarenakan kesadaran semu sebagai ideologi masyarakat desa, yang didasarkan pada nilai keguyuban dan humanisme, mampu menjadi pengikat dan penyatu hubungan antarkelas yang padu. Sehingga stratifikasi sosial antarkelas bias dan cenderung tidak tampak.

Meski begitu, dalam pandangan Marx, bagaimanapun bentuk sumber kesadaran kolektif, kesadaran semu ini membuat kelas bawah tetap berada dalam keadaan tereksploitasi oleh kelas atas. Apapun itu, Karman tetap dalam keadaan tereksploitasi secara sosial karena kebergantungannya pada Haji Bakir selaku tuan tanah.

d. Relasi Struktur Kelas Sosial Sastra dengan Struktur Kelas Sosial Masyarakat

Berdasarkan analisa di atas, dapat disimpulkan adanya dua latar belakang sosial terjadinya peristiwa, yakni: 1) masyarakat desa dan 2) sistem kepartaian komunis. Selanjutnya pada bagian ini akan dianalisis relasi kelas sosial dalam masyarakat desa dan relasi kelas sosial dalam pemerintahan orde baru dalam karya sastra dengan realitas yang sebenarnya. Adapun penjabarannya adalah sebagai berikut:

1) Masyarakat Desa

Pada konteks latar masyarakat desa, menurut Koentjaraningrat, masyarakat adalah kesatuan hidup manusia yang berinteraksi menurut suatu sistem adat istiadat tertentu yang bersifat terus-menerus, dan yang terikat oleh suatu rasa identitas bersama (Koentjaraningrat, 2009,p.118). Masyarakat desa berarti kumpulan individu yang memiliki karakteristik yang pola interaksinya masih sederhana, menjunjung tinggi nilai adatistiadat, dan diikat dengan rasa identitas masyarakat pedesaan (Kurniawan, 2012,p. 65).

Kesederhanaan Karman sebagai bagian dari anggota 
masyarakat desa dapat dilihat saat penerimaannya sebagai pegawai. Pemikiran lugunya semerta-merta hanya ingin dapat dipandang dan dianggap pantas mendampingi anaknya, Rifah, oleh keluarga Haji Bakir. Ia tidak menyadari niat terselubung Triman dan kawan-kawannya. Sikap mudah percaya kepada orang lain adalah bentuk dari kesadaran semu, yang membuat kontradiksi antarkelas sosial menjadi bias bahkan tidak terlihat.

Dalam kenyataannya, pola relasi antarkelas sosial yang berlaku pada masyarakat pedesaan didasarkan pada nilai adat-istiadat yang dijunjung bersama. Nilai itu berupa keguyuban dan humanisme. Keguyuban masyarakat pedesaan memiliki ikatan yang murni, kuat, dan bersifat alamiah diantara anggotanya. Hal ini menyebabkan munculnya sikap toleransi terhadap kemanusiaan yang tinggi, terlepas dari perbedaan yang ada. Sesama manusia harus saling membantu, apapun posisi kelas sosialnya.

2) Sistem Kepartaian Komunis Kenyataan sosial ini jelas terjadi pada masa ketika paham komunis mulai menyebar di Indonesia. Orang-orang yang tidak pro pemerintah akan mencari pemuda-pemudi potensial untuk dijadikan kader demi menegakkan revolusi di Bumi Pertiwi. Dengan memanfaatkan kelemahan, para petinggi partai akan membuat kader-kader muda terikat balas budi dan secara sukarela menyerahkan diri mengabdi pada partai. Hal ini menyebabkan represivitas sistem relasi yang dibangun oleh orang-orang kelas atas dalam sistem kepartaian. Kepatuhan mutlak terbangun karena kepemilikan modal secara langsung maupun tidak langsung. Akhirnya, kelas atas terus berkuasa, dan kekuasaannya digunakan untuk semata-mata kepentingan golongan partai. Karena ikatan rasa balas budi inilah, status kelas atas mereka akan selalu terjaga.

\section{SIMPULAN}

Berdasarkan hasil penelitian dan analisis terhadap novel Kubah karya Ahmad Tohari menggunakan teori sastra Marx, dapat disimpulkan bahwa bentuk ideologi Karman pada awalnya seperti anggota masyarakat pedesaan seperti pada umumnya, yakni ideologi terbuka berupa Pancasila. Hal ini digambarkan secara tidak langsung, dari narasi novel maupun interaksi antartokoh dalam bentuk dialog. Hingga masuknya tokoh Margo dan Triman dalam kehidupan Karman yang sedang terpuruk. Propaganda komunis berbalut revolusi yang ditanamkan oleh Margo dan Triman membuat Karman menjadi sosok yang berbeda. Ideologi tertutup, yaitu ideologi komunis menjadikannya sinis, penuh curiga, dan memiliki pandangan yang berbanding terbalik mengenai posisi kelas-kelas sosial pada tatanan masyarakat Pegaten. Di akhir cerita, Karman kembali lagi pada ideologi lamanya sebagai bagian dari anggota masyarakat Pegaten. Rasa penyesalan yang mendalam terhadap orang-orang yang telah ia sakiti, ditambah sikap terbuka masyarakat Pegaten yang menerimanya dengan ramah, membuat Karman mendapatkan kembali kebersamaan dan kesetaraan dalam pergaulan.

Karman mengalami dinamika ideologi disebabkan oleh: a) taraf ekonominya yang rendah, sehingga mudah bagi Triman dan Margo melakukan intervensi halus yang menjadikan Karman patuh dan masuk dengan sukarela dalam lingkaran pergaulan Margo dan 
Triman; b) ditolaknya lamaran Karman kepada putri Haji Bakirhingga dua kali. Hal ini membawa dampak kekalutan dan ketidakstabilan jiwa Karman sehingga ia tidak dapat berpikir jernih. Akibatnya, mudah bagi Margo dan Triman menanamkan propaganda komunis secara terselubung; c) statusnya sebagai bekas tahanan politik. Keadaan ini membuatnya terasing dan seolah-olah ada batas tak terlihat antara dirinya dan lingkungan sekitar.

Dinamika ideologi Karman tersebut memberi dampak yang bermacam-macam pada masyarakat desa Pegaten, khususnya anggota keluarganya. Sebelumnya ia dikenal sebagai pemuda yang pandai dan cakap. Namun semua itu berubah ketika propaganda yang ditanamkan Margo dan Triman mempengaruhi cara berpikirnya. Meski dikenal sebagai sekretaris Partindo yang pro pemerintah, sesungguhnya Karman terlibat dalam huru-hara penahanan Haji Bakir di tahun enam puluhan. Haji Bakir kala itu adalah tokoh masyarakat, yang dianggap sebagai kaum kapitalis, musuh dari komunis yang menghendaki perubahan sosial dari kaum kelas bawah. Hingga akhirnya di bagian akhir, status Karman yang seorang bekas tahanan politik membuatnya mengharapkan harga asasinya sebagai manusia kembali. Oleh karena itu ia ikut andil dalam pemugaran masjid Haji Bakir. Sumbangannya berupa kubah masjid yang ia kerjakan tanpa pamrih mengundang pujian dari masyarakat Pegaten. Hal ini menunjukkan perubahan ideologi Karman mendapat respon yang positif dan kedatangannya sepenuhnya diterima oleh masyarakat Pegaten. Tak ada yang mengungkit-ungkit masa lalunya.

\section{DAFTAR RUJUKAN}

Hubermann, M. B, \& Miles, A. M. (1994). Qualitative Data Analysis $\left(2^{\text {nd }}\right.$ Edition). London: Sage Publication.

Kaelan, MS.(2012). Metode Penelitian Kualitatif Interdisipliner. Yogyakarta: Paradigma.

Kurniawan, H.(2012). Teori, Metode, dan Aplikasi Sosiologi Sastra. 2012. Yogyakarta: Graha Ilmu.

Ritzer, G., \& Goodman, D.J.(2011).Teori Sosiologi Modern. Jakarta: Prenada Media.

Saifuddin, A.F. (2009). Pengantar Teori-Teori Sosial; dari Teori Fungsionalisme Hingga PostModernisme. Jakarta: Yayasan Obor Indonesia.

Ratna, N.K. (2010). Metodologi Penelitian: Kajian Budaya dan Ilmu Sosial Humaniora pada Umumnya. Yogyakarta: Pustaka Pelajar.

Sugiyono. (2015).Metode Penelitian Kualitatif dan $\mathrm{R}$ dan D. Bandung: Alfabeta.

Suharsaputra, U.(2012).Metode Penelitian; Kuantitatif, Kualitatif, dan Tindakan. Bandung:PT Refika Aditama.

Suseno, F. M. (1999).Pemikiran Karl Marx; dari Sosialisme Utopis ke Perselisiban Revisionisme. Jakarta: PT Gramedia Pustaka Utama. 